\title{
Cardiac Masses: The Role of Cardiovascular Imaging in the Differential Diagnosis
}

\author{
Constantina Aggeli 1,*, Yannis Dimitroglou 1® , Leonidas Raftopoulos ${ }^{1}$, Georgia Sarri ${ }^{1}$, \\ Sophie Mavrogeni ${ }^{2}$, Joyce Wong ${ }^{3}$, Eleftherios Tsiamis ${ }^{1}$ and Costas Tsioufis ${ }^{1}$ \\ 1 First Department of Cardiology, General Hospital of Athens Hippokration, University of Athens Medical \\ School, 11527 Athens, Attica, Greece; dimiyann@hotmail.com (Y.D.); lraftop@otenet.gr (L.R.); \\ georgiasarri@hotmail.com (G.S.); ltsiamis@otenet.gr (E.T.); ktsioufis@hippocratio.gr (C.T.) \\ 2 Department of Cardiology, Onassis Cardiac Surgery Centre, 17674 Kallithea, Attica, Greece; \\ sophie.mavrogeni@gmail.com \\ 3 Department of Cardiology, Harefield Hospital and Royal Brompton Hospital, London UB96JH, UK; \\ j.wong@rbht.nhs.uk \\ * Correspondence: dina.aggeli@gmail.com
}

Received: 9 November 2020; Accepted: 8 December 2020; Published: 14 December 2020

\begin{abstract}
Cardiac masses are space occupying lesions within the cardiac cavities or adjacent to the pericardium. They include frequently diagnosed clinical entities such as clots and vegetations, common benign tumors such as myxomas and papillary fibroelastomas and uncommon benign or malignant primary or metastatic tumors. Given their diversity, there are no guidelines or consensus statements regarding the best diagnostic or therapeutic approach. In the past, diagnosis used to be made by the histological specimens after surgery or during the post-mortem examination. Nevertheless, evolution and increased availability of cardiovascular imaging modalities has enabled better characterization of the masses and the surrounding tissue. Transthoracic echocardiography using contrast agents can evaluate the location, the morphology and the perfusion of the mass as well as its hemodynamic effect. Transesophageal echocardiography has increased spatial and temporal resolution; hence it is superior in depicting small highly mobile masses. Cardiac magnetic resonance and cardiac computed tomography are complementary providing tissue characterization. The scope of this review is to present the role of cardiovascular imaging in the differential diagnosis of cardiac masses and to propose a step-wise diagnostic algorithm, taking into account the epidemiology and clinical presentation of the cardiac masses, as well as the availability and the incremental value of each imaging modality.
\end{abstract}

Keywords: cardiac tumors; cardiac malignancies; echocardiography; transesophageal echocardiography; contrast agents; cardiac magnetic resonance; cardiac computed tomography

\section{Introduction}

The diagnosis of space occupying lesions or masses in the heart can be done either in the context of investigation of a specific clinical symptomatology or incidentally, usually in the context of a cardiac imaging study performed for another reason. Cardiac masses can be classified as lesions that resemble tumors (clots, vegetations, calcifications or other rare lesions) and as benign or malignant, primary or metastatic, intracardial, or pericardial tumors [1-3]. Primary tumors are usually benign, with more than $50 \%$ chance of being a myxoma. Primary malignant tumors are rare, accounting for less than a quarter of primary heart tumors, in the majority of cases being sarcomas [4,5]. However, in autopsy studies a cardiac tumor most commonly represents a metastatic malignant tumor. The prevalence of primary cardiac tumors is 1:2000, while of metastatic 1:100 autopsies, reflecting a ratio of secondary 
to primary patients in the range of 20:1. The incidence of cardiac metastases varies among autopsy studies from $2.3 \%$ to $18.3 \%$ in patients with extracardiac malignant tumors $[1,2,6]$.

Cardiac imaging modalities, including transthoracic (TTE) or transesophageal (TEE) echocardiography, cardiac magnetic resonance (CMR), cardiac computed tomography (CT), and ${ }^{18}$ Ffluorodeoxyglucose positron emission tomography $\left({ }^{18} \mathrm{~F}\right.$ FDG-PET), have a complementary and reinforcing role for the evaluation of cardiac masses [7]. Given the diversity of cardiac masses, (from clots or vegetations to primary or metastatic malignant tumors), there are no guidelines or consensus statements regarding the best diagnostic or therapeutic approach. The scope of this review is to present the role of cardiovascular imaging in the differential diagnosis of cardiac masses and to propose a step-wise diagnostic algorithm, taking into account their epidemiology and clinical presentation, as well as the availability and the incremental value of each imaging modality.

\section{Diagnostic Approach of Patients Presenting with Cardiac Masses}

Evaluation begins with patient history and clinical examination including electrocardiogram followed by imaging data regarding size, localization, hemodynamic effects, vascularity, tissue characterization, and possible infiltration or compression of surrounding tissue. Clinicians should be familiar with epidemiological, clinical, and imaging features of most common cardiac masses (Table 1). Comprehensive presentation of those features is beyond the scope of the present review.

Table 1. Clinical, echocardiographic and cardiac magnetic resonance (CMR) characteristics of cardiac masses.

\begin{tabular}{|c|c|c|c|c|c|c|}
\hline & $\begin{array}{c}\text { Common } \\
\text { Age at } \\
\text { Presentation }\end{array}$ & $\begin{array}{l}\text { Common } \\
\text { Location at } \\
\text { Heart }\end{array}$ & $\begin{array}{c}\text { Clinical } \\
\text { Manifestations }\end{array}$ & Echocardiography & $\mathrm{CT}$ & CMR \\
\hline \multicolumn{7}{|l|}{$\begin{array}{l}\text { Benign primary heart } \\
\text { tumors }\end{array}$} \\
\hline Myxoma & $\begin{array}{c}\text { Early } \\
\text { (familial) or } \\
\text { middle } \\
\text { adulthood }\end{array}$ & $\begin{array}{l}\text { LA, atrial } \\
\text { septum, any } \\
\text { other site }\end{array}$ & $\begin{array}{l}\text { Emboli, flow } \\
\text { obstruction, } \\
\text { systemic } \\
\text { symptoms }\end{array}$ & $\begin{array}{c}\text { Mildly lobar, } \\
\text { heterogeneous } \\
\text { echodensity, } \\
\text { usually mobile } \\
\text { (with or without } \\
\text { stalk) }\end{array}$ & $\begin{array}{l}\text { Heterogeneous, } \\
\text { low attenuation, } \\
\text { may be calcified }\end{array}$ & $\begin{array}{l}\text { Isointense T1w, } \\
\text { High T2w, } \\
\text { heterogeneous } \\
\text { LGE }\end{array}$ \\
\hline Papillary fibroelastoma & $\begin{array}{l}\text { Middle or } \\
\text { late } \\
\text { adulthood }\end{array}$ & Cardiac valves & $\begin{array}{c}\text { Usually } \\
\text { asymptomatic, } \\
\text { emboli }\end{array}$ & $\begin{array}{c}\text { Circular, } \\
\text { pedunculated, } \\
\text { non-protruding, } \\
\text { usually not } \\
\text { causing valve } \\
\text { dysfunction }\end{array}$ & $\begin{array}{c}\text { Smooth, } \\
\text { pedunculated }\end{array}$ & $\begin{array}{l}\text { Iso/hypointense } \\
\text { T1w, high T2w, } \\
\text { LGE, highly } \\
\text { mobile, consider } \\
\text { TEE }\end{array}$ \\
\hline Lipoma & Adulthood & $\begin{array}{l}\text { Left ventricle, } \\
\text { any other site }\end{array}$ & $\begin{array}{c}\text { Usually } \\
\text { asymptomatic, } \\
\text { arrhythmias, } \\
\text { flow obstruction }\end{array}$ & Homogeneous & $\begin{array}{c}\text { Smooth, } \\
\text { homogenous } \\
\text { encapsulated, } \\
\text { fat attenuation, } \\
\text { no enhancement } \\
\text { with contrast }\end{array}$ & $\begin{array}{l}\text { High T1w, T2w, } \\
\text { no LGE, } \\
\text { suppressed with } \\
\text { SPIR }\end{array}$ \\
\hline Rhabdomyoma & $\begin{array}{l}\text { Infancy or } \\
\text { early } \\
\text { childhood }\end{array}$ & $\begin{array}{c}\text { Ventricles, } \\
\text { atrioventricular } \\
\text { valves }\end{array}$ & $\begin{array}{c}\text { Usually } \\
\text { asymptomatic, } \\
\text { flow obstruction, } \\
\text { heart failure, } \\
\text { arrhythmias }\end{array}$ & $\begin{array}{l}\text { Homogenous, } \\
\text { slightly echogenic, } \\
\text { can be multiple }\end{array}$ & $\begin{array}{l}\text { Attenuation } \\
\text { similar to } \\
\text { myocardium, } \\
\text { intramural }\end{array}$ & $\begin{array}{l}\text { Isointense T1w, } \\
\text { iso/hyperintense } \\
\text { T2w, no LGE }\end{array}$ \\
\hline Fibroma & $\begin{array}{c}\text { Early } \\
\text { childhood }\end{array}$ & $\begin{array}{l}\text { Intraventricular } \\
\text { septum, } \\
\text { ventricles }\end{array}$ & $\begin{array}{c}\text { Usually } \\
\text { asymptomatic, } \\
\text { arrhythmias }\end{array}$ & $\begin{array}{c}\text { Heterogeneous, } \\
\text { echogenic, } \\
\text { non-contractible, } \\
\text { can mimic HCM }\end{array}$ & $\begin{array}{l}\text { Soft tissue } \\
\text { attenuation, } \\
\text { low contrast } \\
\text { enhancement, } \\
\text { may be calcified }\end{array}$ & $\begin{array}{l}\text { Isointense T1w, } \\
\text { Low T2w, high } \\
\text { LGE }\end{array}$ \\
\hline Hemangioma & Any age & Any other site & $\begin{array}{l}\text { Usually } \\
\text { asymptomatic, } \\
\text { dyspnoea }\end{array}$ & $\begin{array}{l}\text { Highly echogenic } \\
\text { with contrast } \\
\text { infusion, may } \\
\text { resemble a cavity }\end{array}$ & $\begin{array}{l}\text { Heterogeneous, } \\
\text { high contrast } \\
\text { enhancement, } \\
\text { may be calcified }\end{array}$ & $\begin{array}{l}\text { Heterogeneous, } \\
\text { high T1w, } \\
\text { Very high T2w, } \\
\text { centripetal } \\
\text { progression on } \\
\text { first pass, } \\
\text { heterogeneous } \\
\text { LGE, }\end{array}$ \\
\hline
\end{tabular}


Table 1. Cont.

\begin{tabular}{|c|c|c|c|c|c|c|}
\hline & $\begin{array}{c}\text { Common } \\
\text { Age at } \\
\text { Presentation }\end{array}$ & $\begin{array}{c}\text { Common } \\
\text { Location at } \\
\text { Heart }\end{array}$ & $\begin{array}{c}\text { Clinical } \\
\text { Manifestations }\end{array}$ & Echocardiography & $\mathrm{CT}$ & CMR \\
\hline \multicolumn{7}{|l|}{$\begin{array}{l}\text { Malignant primary heart } \\
\text { tumors }\end{array}$} \\
\hline Angiosarcoma & $\begin{array}{l}\text { Early and } \\
\text { middle } \\
\text { adulthood }\end{array}$ & RA, pericardium & $\begin{array}{l}\text { Constitutional } \\
\text { symptoms, heart } \\
\text { failure, } \\
\text { pericardial } \\
\text { effusion }\end{array}$ & $\begin{array}{l}\text { Heterogeneous, } \\
\text { highly echogenic } \\
\text { with contrast } \\
\text { infusion }\end{array}$ & $\begin{array}{l}\text { Heterogeneous, } \\
\text { irregular, } \\
\text { low attenuation }\end{array}$ & $\begin{array}{c}\text { Heterogeneous } \\
\text { T1w, T2w LGE, } \\
\text { early } \\
\text { enhancement at } \\
\text { first pass }\end{array}$ \\
\hline Rhabomyosarcoma & $\begin{array}{l}\text { Childhood, } \\
\text { early } \\
\text { adulthood }\end{array}$ & $\begin{array}{l}\text { Ventricles, any } \\
\text { other site }\end{array}$ & Heart failure & $\begin{array}{l}\text { Normal-high } \\
\text { echodensity }\end{array}$ & $\begin{array}{l}\text { Irregular, } \\
\text { low attenuation }\end{array}$ & $\begin{array}{l}\text { Isointense T1w, } \\
\text { high T2w, } \\
\text { usually } \\
\text { homogenous } \\
\text { LGE }\end{array}$ \\
\hline UPS/Myxofibrosarcoma & $\begin{array}{l}\text { Early and } \\
\text { middle } \\
\text { adulthood }\end{array}$ & $\begin{array}{l}\text { Left atrium, any } \\
\text { other site }\end{array}$ & $\begin{array}{c}\text { Flow } \\
\text { obstruction/heart } \\
\text { failure, } \\
\text { pericardial } \\
\text { effusion, } \\
\text { metastatic }\end{array}$ & $\begin{array}{l}\text { Heterogeneous, } \\
\text { normal-high } \\
\text { echodensity }\end{array}$ & $\begin{array}{l}\text { Heterogeneous, } \\
\text { low attenuation }\end{array}$ & $\begin{array}{l}\text { Heterogeneous } \\
\text { T1w, T2w LGE }\end{array}$ \\
\hline Lymphoma & Adulthood & $\begin{array}{l}\text { RA, any other } \\
\text { site }\end{array}$ & $\begin{array}{c}\text { Pericardial } \\
\text { effusion, flow } \\
\text { obstruction/heart } \\
\text { failure }\end{array}$ & $\begin{array}{l}\text { Any size and } \\
\text { shape }\end{array}$ & $\begin{array}{l}\text { Normal to low } \\
\text { attenuation, } \\
\text { heterogeneous } \\
\text { contrast } \\
\text { enhacncement }\end{array}$ & $\begin{array}{l}\text { Isointentse T1w, } \\
\text { T2w, minimal } \\
\text { LGE }\end{array}$ \\
\hline Mesothelioma & Adulthood & Pericardium & $\begin{array}{l}\text { Pericardial } \\
\text { effusion }\end{array}$ & Heterogeneous & $\begin{array}{c}\text { Variable } \\
\text { characteristics }\end{array}$ & $\begin{array}{l}\text { Isointense T1w, } \\
\text { Heterogeneous } \\
\text { T2w, high LGE }\end{array}$ \\
\hline \multicolumn{7}{|l|}{ Metastatic tumors } \\
\hline Melanoma & Adulthood & Any site & $\begin{array}{c}\text { Flow } \\
\text { obstruction/heart } \\
\text { failure, } \\
\text { pericardial } \\
\text { effusion }\end{array}$ & $\begin{array}{l}\text { Heterogeneous, } \\
\text { highly echogenic } \\
\text { with contrast } \\
\text { infusion }\end{array}$ & $\begin{array}{l}\text { Similar to soft } \\
\text { tissue, hard to } \\
\text { recognize }\end{array}$ & $\begin{array}{c}\text { High T1w, } \\
\text { low T2w } \\
\text { heterogeneous } \\
\text { LGE }\end{array}$ \\
\hline Other metastatic tumors & Adulthood & $\begin{array}{l}\text { Pericardium, } \\
\text { any site }\end{array}$ & $\begin{array}{c}\text { Flow } \\
\text { obstruction/heart } \\
\text { failure, } \\
\text { pericardial } \\
\text { effusion }\end{array}$ & $\begin{array}{l}\text { Heterogeneous, } \\
\text { highly echogenic } \\
\text { with contrast } \\
\text { infusion }\end{array}$ & $\begin{array}{l}\text { Solid, similar to } \\
\text { soft tissue } \\
\text { attenuation, } \\
\text { moderate to } \\
\text { high contrast } \\
\text { enhancement }\end{array}$ & $\begin{array}{l}\text { Low T1w, high } \\
\text { T2w, } \\
\text { heterogeneous } \\
\text { LGE }\end{array}$ \\
\hline \multicolumn{7}{|l|}{$\begin{array}{l}\text { Non-neoplasmatic heart } \\
\text { masses }\end{array}$} \\
\hline Clots & Adulthood & LAA, LV apex & Emboli & $\begin{array}{l}\text { Acute: Low } \\
\text { echodensity } \\
\text { Chronic: High } \\
\text { echodensity } \\
\text { No perfusion with } \\
\text { contrast agents }\end{array}$ & $\begin{array}{l}\text { No contrast } \\
\text { enhancement, } \\
\text { may be calcified }\end{array}$ & $\begin{array}{c}\text { No EGE/LGE } \\
\text { Acute: } \\
\text { Isointense to } \\
\text { high T1w, T2w } \\
\text { Subacute: High } \\
\text { T1w, Low T2w } \\
\text { Chronic: Low } \\
\text { T1w, T2w }\end{array}$ \\
\hline Vegetation & Adulthood & Cardiac valves & $\begin{array}{c}\text { Valve } \\
\text { dysfunction, } \\
\text { emboli, heart } \\
\text { failure }\end{array}$ & $\begin{array}{l}\text { Highly mobile, } \\
\text { oscillating } \\
\text { protruding, valve } \\
\text { dysfunction, }\end{array}$ & $\begin{array}{l}\text { Low attenuation, } \\
\text { may recognize, } \\
\text { perivalvular } \\
\text { extension, } \\
\text { fistulas, abscess }\end{array}$ & $\begin{array}{l}\text { Highly mobile, } \\
\text { consider TEE }\end{array}$ \\
\hline $\begin{array}{l}\text { Non-neoplasmatic } \\
\text { calcified masses }\end{array}$ & Adulthood & $\begin{array}{l}\text { Usually } \\
\text { posterior mitral } \\
\text { annulus }\end{array}$ & $\begin{array}{c}\text { Usually } \\
\text { asymptomatic }\end{array}$ & $\begin{array}{l}\text { Very high } \\
\text { echodensity }\end{array}$ & $\begin{array}{l}\text { Heterogeneous, } \\
\text { calcified }\end{array}$ & $\begin{array}{l}\text { Signal loss, } \\
\text { consider CT }\end{array}$ \\
\hline Pericardial cysts & Adulthood & Pericardium & $\begin{array}{l}\text { Usually } \\
\text { asymptomatic, } \\
\text { external } \\
\text { compression }\end{array}$ & $\begin{array}{l}\text { Low echodensity, } \\
\text { typically no } \\
\text { perfusion with } \\
\text { contrast agents }\end{array}$ & $\begin{array}{l}\text { Presence of wall, } \\
\text { fluid attenuation }\end{array}$ & $\begin{array}{l}\text { Depends on the } \\
\text { fluid, usually } \\
\text { isointense T1w, } \\
\text { high T2w, no } \\
\text { LGE }\end{array}$ \\
\hline Lipomatous Hypertrophy & $\begin{array}{l}\text { Late } \\
\text { adulthood }\end{array}$ & Atrial septum & $\begin{array}{c}\text { Usually } \\
\text { asymptomatic, } \\
\text { arrhythmias }\end{array}$ & $\begin{array}{l}\text { Homogeneous } \\
\text { dumbbell } \\
\text { appearance of } \\
\text { atrial septum }\end{array}$ & Fat attenuation & $\begin{array}{l}\text { High T1w, T2w, } \\
\text { no LGE, } \\
\text { suppressed with } \\
\text { SPIR }\end{array}$ \\
\hline
\end{tabular}

CMR: Cardiac magnetic resonance; CT: Computed tomography; EGE: Early gadolinium enhancement; HCM: Hypertrophic cardiomyopathy; LA: Left atrium; LAA: Left atrium appendage; LGE: Late gadolinium enhancement; LV: Left ventricle; RA: Right atrium; SPIR: Spectral presaturation with inversion recovery; TEE: Transesophageal echocardiography; UPS: Undifferentiated pleomorphic sarcoma. 
Knowledge of epidemiological data regarding frequency of each tumor, in the various age groups or between sexes and identification of accompanying symptoms and signs improves diagnostic accuracy of imaging tools.

The most frequent masses in the heart are clots or vegetations frequently accompanying a relevant clinical scenario such as mitral stenosis, atrial fibrillation, myocardial infarction, myocarditis with a very low ejection fraction, or infective endocarditis, respectively (Figures 1 and 2).

Approximately $90 \%$ of the surgically-removed tumors are benign [4]. Most of these benign tumors are myxomas $(80 \%)$, while the remaining ones are (in descending order) papillary fibroelastomas, fibromas, lipomas, and, even more rarely, calcified amorphous tumors, hemangiomas, teratomas, single developmental cysts, and rhabdomyomas [8-11]. Only about $10 \%$ of the primary cardiac tumors surgically removed are malignant: $90 \%$ of them identified as sarcomas or lymphomas [11].

On the other hand, secondary cancer metastases in myocardium and pericardium are more common. Secondary metastases can occur due to direct invasion of the primary tumor to the adjacent heart tissue (i.e., in case of breast or lung cancer) or hematogenous (arterial/venous) and lymphoid dispersion [12-14]. In certain tumor types, a genetic predisposition has been identified [15].

In infants and children, rhabdomyoma is the most frequent tumor type, followed by myxoma and fibroma $[16,17]$. Primary malignant tumors (usually rhabdomyosarcoma and teratoma) are very rare.
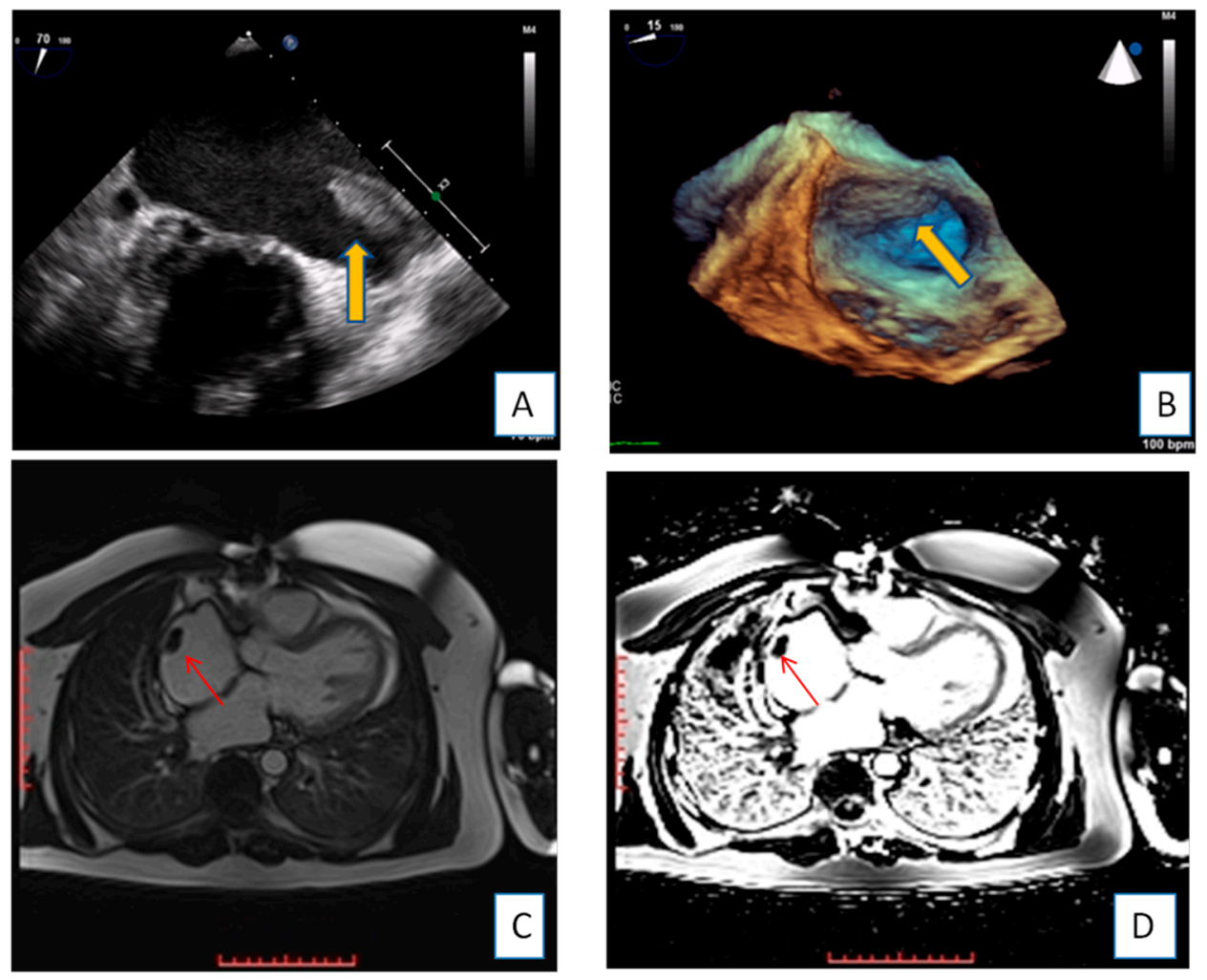

Figure 1. Transesophageal echocardiography depicting the left atrial appendage using $2 \mathrm{D}$ and $3 \mathrm{D}$ approach ((A,B), respectively). A huge thrombus (arrows) is demonstrated in the upper part of the "coumadin ridge" is an elderly woman with severe mitral stenosis. Clot in the RA (red arrows). Cine and EGE imaging $((\mathbf{C}, \mathbf{D})$ respectively). 


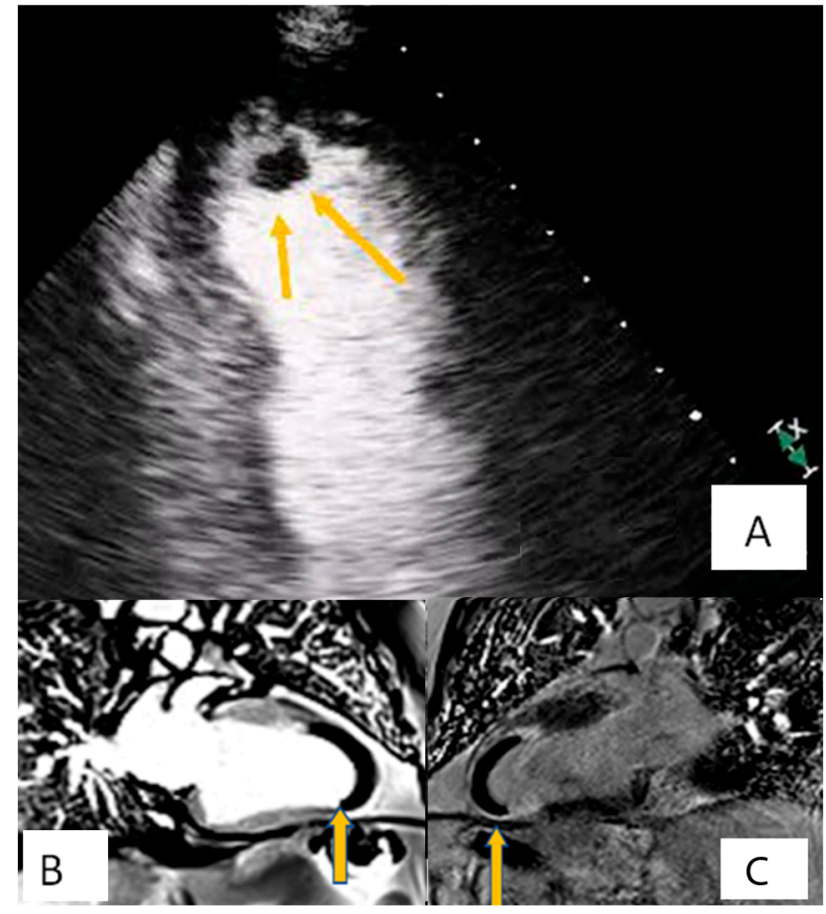

Figure 2. Patient presenting with anterior myocardial infarction the second day after primary percutaneous transluminar coronary angioplasty (PTCA). Apical 4-chamber view. (A) A lesion is depicted on cardiac apex (yellow arrows), mobile, without vasculature, findings compatible with clot. $(\mathbf{B}, \mathbf{C})$ Large laminar LV thrombus adjacent to an area of apical myocardial infarction. Two chambers EGE (image (B)) and LGE (image (C)) respectively.

Clinical symptoms and signs usually depend on the location of the tumor rather than its histological type $[18,19]$. Primary benign tumors as well as secondary malignant tumors may cause myocardial or valve dysfunction and could be accompanied by heart failure symptoms (most commonly dyspnea), angina, syncope and electrical disturbances of the heart or even fatal arrhythmias [20,21]. Pericardial effusion with or without tamponade is characteristic of malignant tumors (Figure 3). Embolism due to tumor particles is a relatively frequent complication, occurring in a quarter of all cardiac tumor patients, and it is related to anatomical and histological characteristics of each tumor. Constitutional manifestations such as weight loss, malaise, and fatigue have also been described. However, most cardiac masses remain asymptomatic or present with mild and atypical symptoms [1-3]. Hence, they are usually recognized during outpatient care.
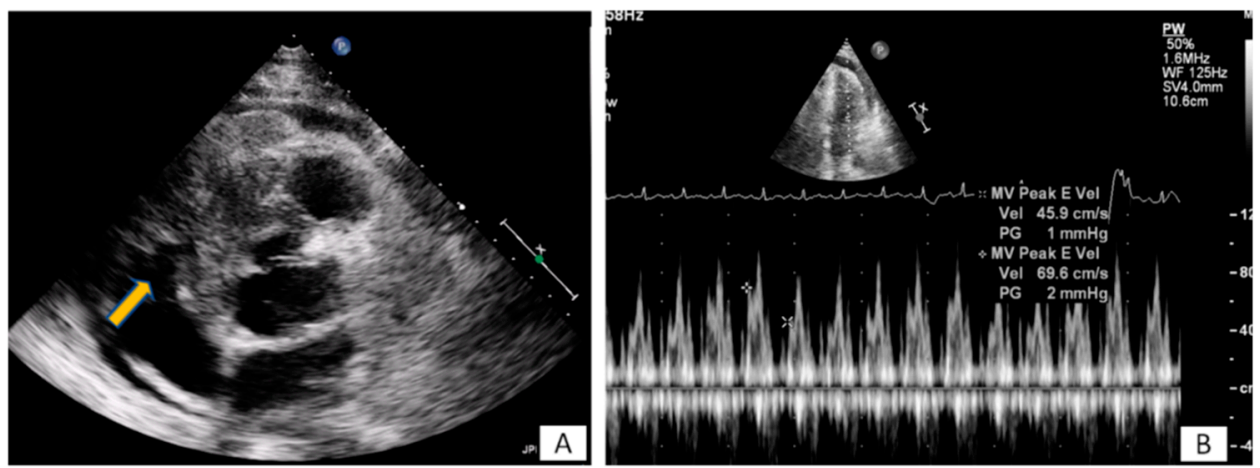

Figure 3. (A) A 65-year-old patient with fever and dyspnea for 15 days. Transthoracic echo (modified short axis view) demonstrated an amorphous mass (arrow) infiltrating the tricuspid annulus, right ventricular free wall and pericardium, causing a moderate in size pericardial effusion. (B) The pericardial fluid led to tamponade (B). Biopsy revealed a lymphoma. 


\section{Information Extracted by the Use of the Imaging Modalities}

Certain cardiac tumors tend to appear in specific locations and structures [22]. Myxomas usually develop within the left atrium [23] (Figure 4). Most sarcomas also develop within the left atrium and can be mistakenly confused pre-operatively with myxomas. Angiosarcomas, on the other hand, are more often found within the right atrium [24]. Rhabdomyomas and fibromas are located in the ventricles, while papillary fibroelastomas are located on the valves [25] (Figure 5). Finally, metastatic tumors can be located anywhere in the heart, depending on the way cancer has spread [26]. In most cases masses spread through inferior vena cava to the right atrium (Figure 6).
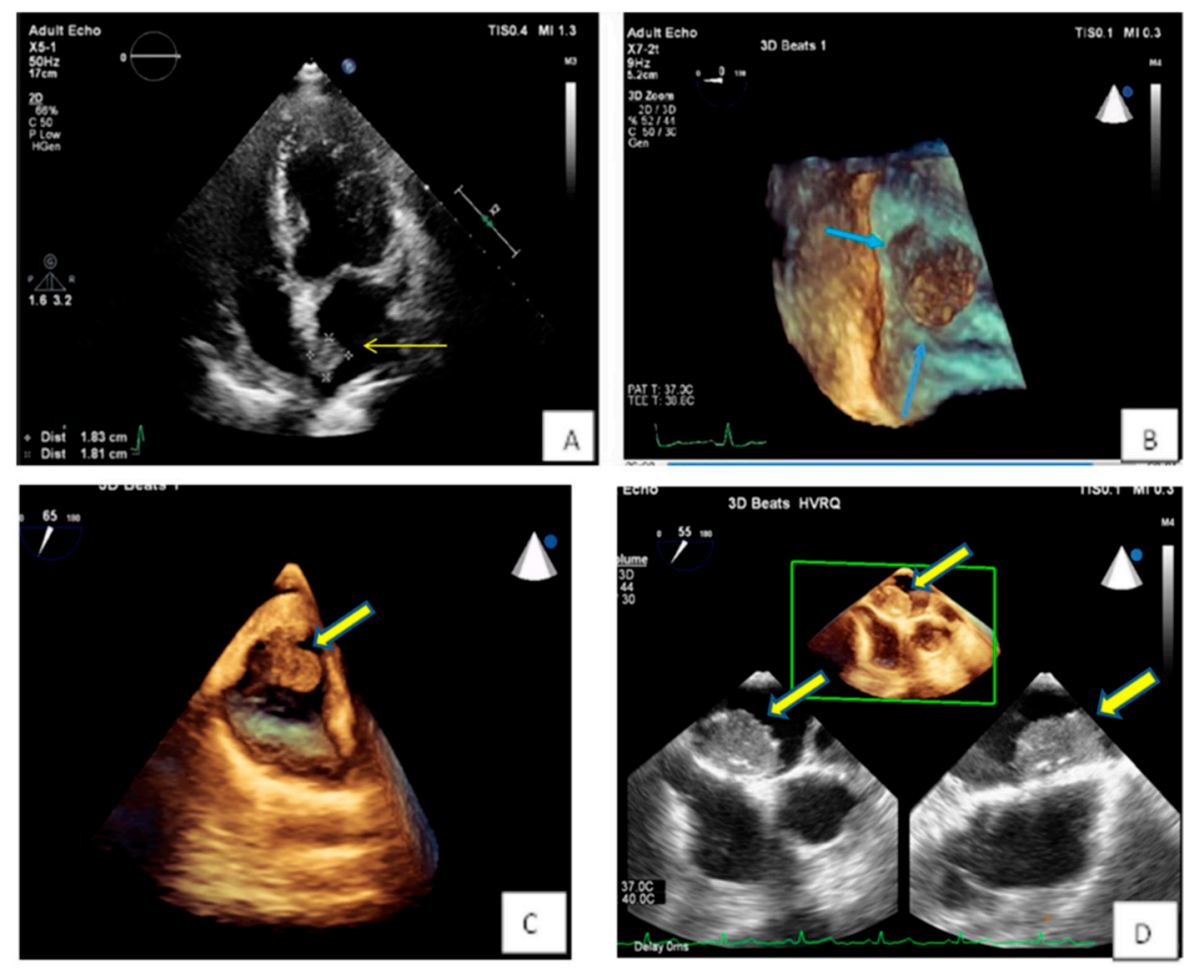

Figure 4. $(\mathbf{A}, \mathbf{B})$ Spherical lesion $1.8 \times 1.8 \mathrm{~cm}$ attached through a wide base close to fossa ovalis was depicted at TTE (A) (yellow arrow) and subsequently TEE (B) (blue arrows-3D zoom). The location of the tumor in the left atrium as well as its morphological characteristics are compatible with a myxoma. (C) 3D TEE showing a polypoid (yellow arrow), with a smooth or mildly lobar surface located at the entrance of the inferior vena cava. Echocardiographic findings are consistent with a myxoma in a rare position. (D) 3D TEE depicting a large mass with spot calcific areas located at the fossa ovalis with a wide base, findings consistent with a left atrium myxoma. Please note the areas with higher echogenicity within the mass (yellow arrows). 


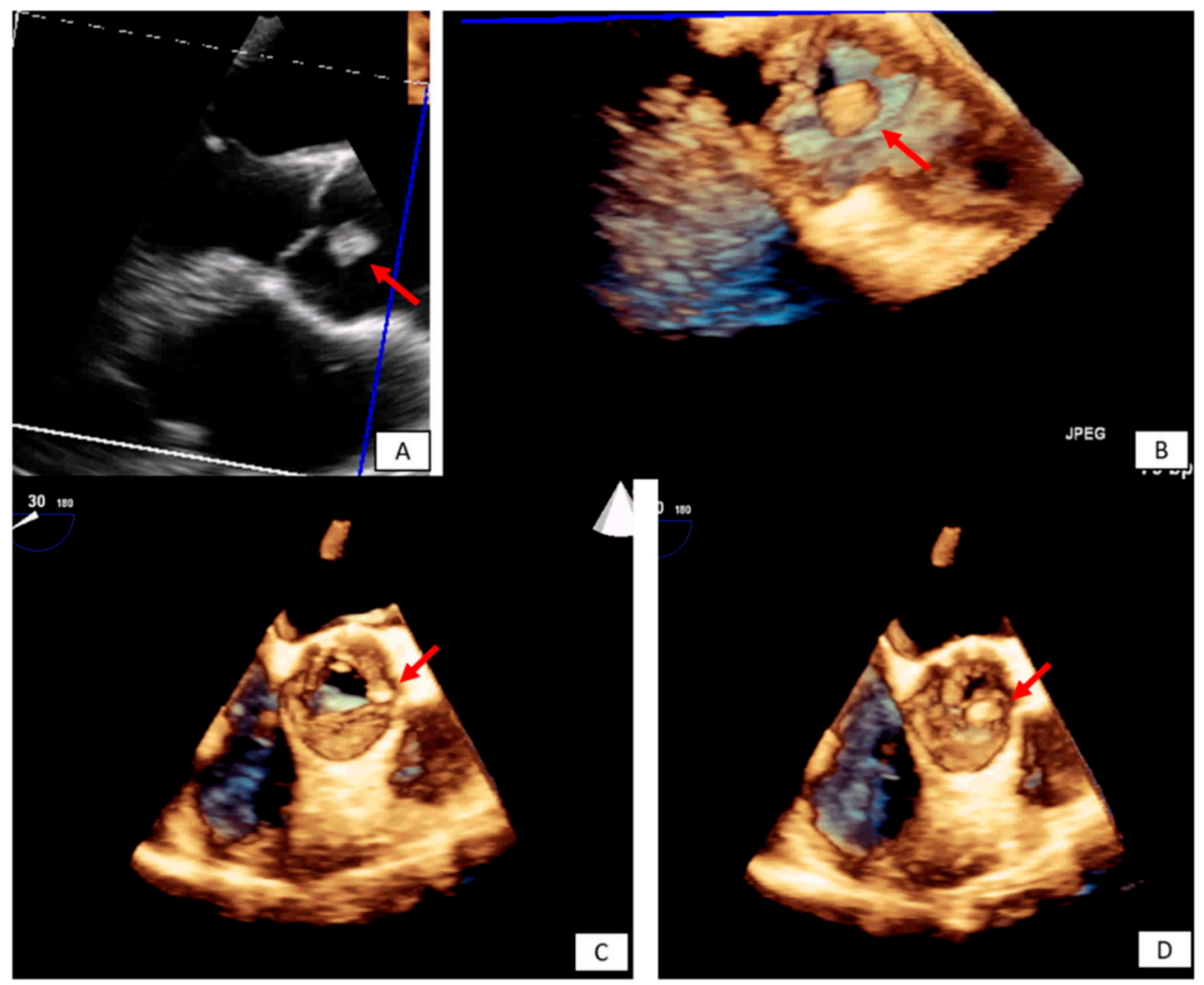

Figure 5. Incidental finding on TTE in an asymptomatic patient followed by TEE. The transesophageal image revealed a papillary fibroelastoma attached to the left cusp of the aortic valve (red arrows) 3D TEE with cropping in long axis $(\mathbf{A}, \mathbf{B})$, and short axis view $((\mathbf{C}, \mathbf{D})$ during systole and diastole, respectively). Please note that the pedunculated lesion is attached on the tip of the aortic surface of the aortic valve, is not protruding in the LVOT during systole and doesn't lead to valve destruction or insufficiency. 

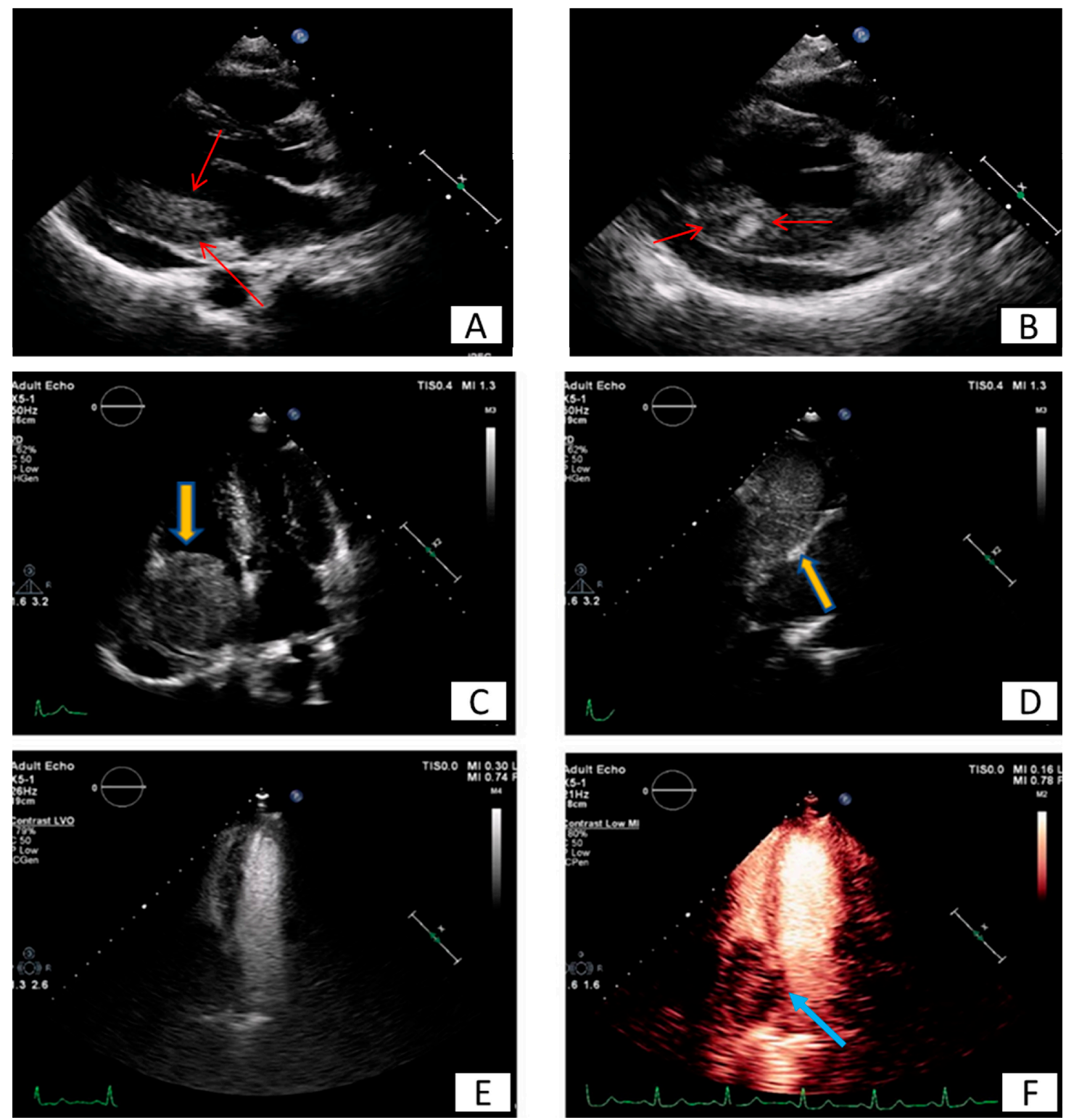

Figure 6. Long (A) and modified short axis (B) view of transthoracic echocardiography in a young female patient with metastatic carcinoma. Note the presence of pericardial effusion and the increased echogenicity and inhomogeneity of the basal posterior myocardial wall finding consistent with malignancy (red arrows). (C-F) Patient presenting with dyspnea on exertion and right heart failure symptoms during last months. A large mass $(5.2 \times 4.8 \mathrm{~cm})$ is depicted inside the right atrium $(C)$, originating from inferior vena cava (D). Utilizing echo contrast agents, the increased vasculature of the mass is revealed, a finding supportive of malignancy $(\mathbf{E}, \mathbf{F})$.

\subsection{Transthoracic Echocardiography}

Echocardiography is simple to perform, non-invasive, widely-available, and affordable [3]. It provides accurate information on the morphology, localization, and mobility of the tumor and finally can evaluate its hemodynamic impact [27-29]. Transthoracic echocardiography (TTE) provides information about the echodensity and degree of calcification of the mass. Continuous Doppler velocities as well as Color Doppler can provide information on the hemodynamic effect of the mass. Furthermore, echo contrast agents (LVO or perfusion modalities) can provide significant information on morphological characteristics and tumor vascularity-perfusion [30-32] (Figure 7). Speckle tracking imaging can also highlight the non-contractible nature of non-mobile masses such as fibromas [31,33]. 

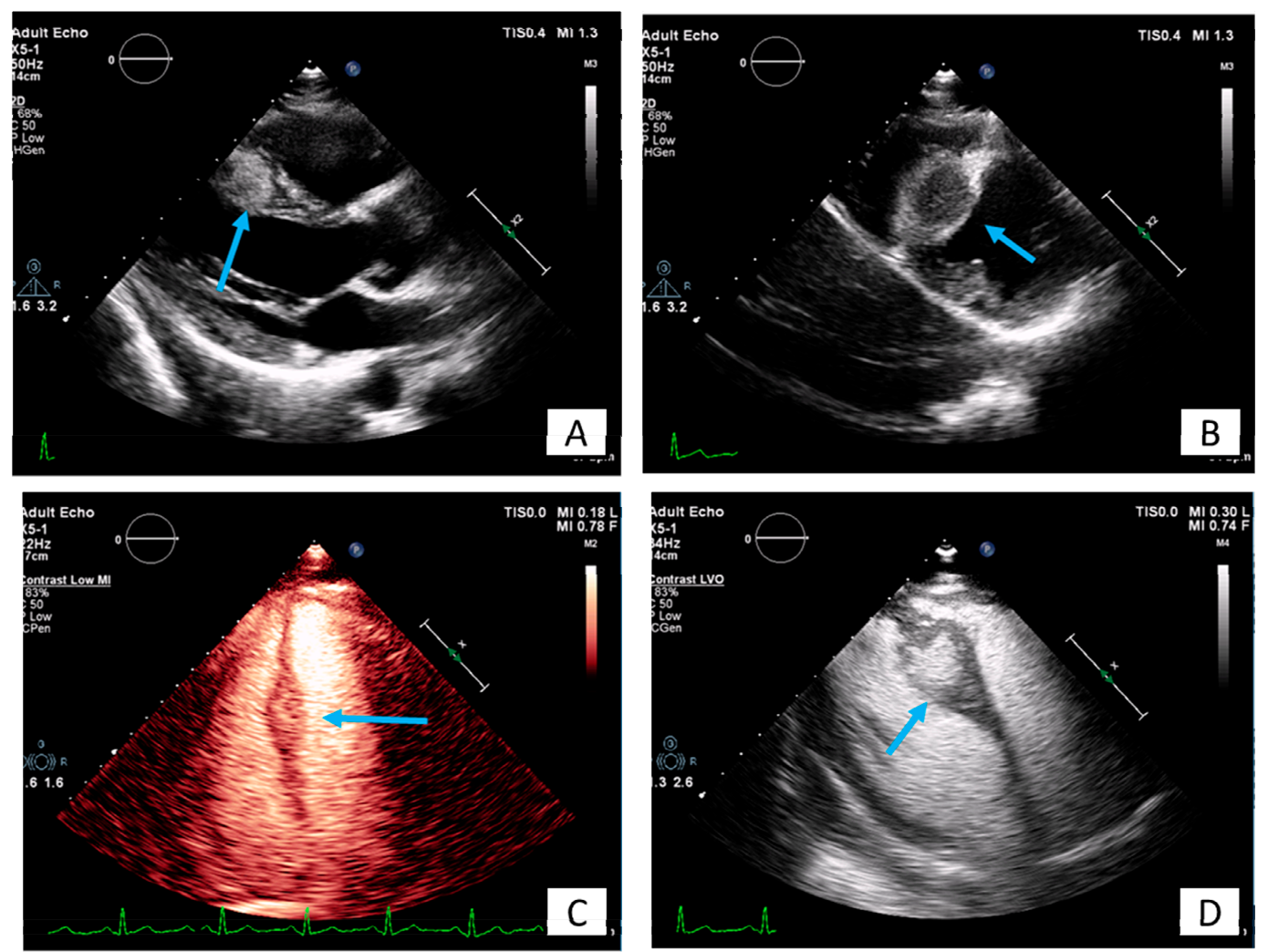

Figure 7. A 35-year-old patient with a round lesion located at the middle of intraventricular septum, known from 5 years ago, stable in size during follow-up (A,B). Using contrast agents, the mass is highly echogenic indicating increased vasculature with a surrounding halo (C,D). It is most likely an intramural hemangioma.

\subsection{Transesophageal Echocardiography}

Transesophageal echocardiography, especially when performed utilizing three-dimensional imaging techniques, can provide a detailed anatomical study of the mass and its surrounding tissues [34,35]. TEE is superior compared to TTE and can accurately highlight the relationship between the mass and the surrounding tissue especially for atrial tumors. It is also superior to CMR when imaging small and highly mobile masses such as vegetations, papillary fibroelastomas or other masses adjacent to the cardiac valves. It is worth to point out that for tumors in the atria, TEE is of high diagnostic utility contributing to the early differential diagnosis. Furthermore, TEE may provide information for the presence of infective endocarditis' complications such as abscess and infective infiltration of the surroundings tissues (Figure 8). 


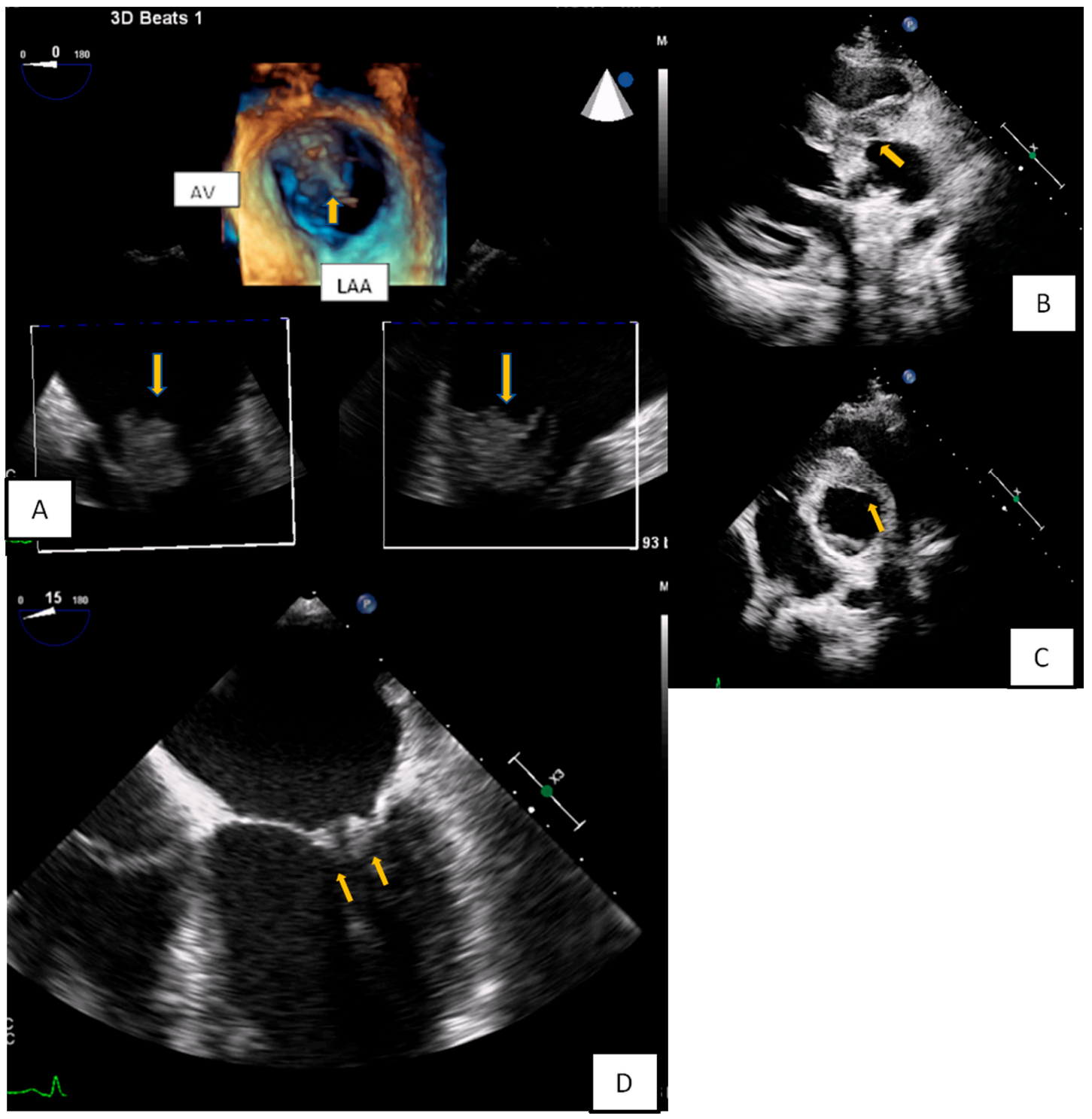

Figure 8. (A) 3D-TEE in a patient evaluated for a possible endocarditis. A large multilobular amorphous mass (vegetation) is found attached on the right commissure (3rd hour) of the anterior and posterior leaflet (AV: Aortic valve, LAA: Left atrial appendage). (B,C) A huge abscess infiltrating the aortic root and the aortomitral curtain in a young febrile patient with prosthetic aortic valve. (D) Transesophageal echocardiography-4 Chamber view. Increased thickness and echogenicity of both the tips of the leaflets in a patient with lupus erythromatosus endocarditis.

\subsection{Computed Tomography}

$\mathrm{CT}$ and CMR are complementary and useful especially if surgical resection of the tumor is planned [36-39]. For both techniques acquisition protocols may vary and should be guided by clinical scenario and echocardiography data. CT can provide information about tumor vascularity (using contrast enhancement), the extent of tumor calcification, the presence of fat tissue, as well as the staging of the patient [39-41]. CT is the modality of choice in masses adjacent to the prosthetic valves and is superior to CMR for calcified masses (Figure 9). Compared to CMR, CT has superior spatial resolution facilitating 3D reconstruction [40,42]. Recent advances using spectral CT have also improved tissue characterization with decrease of radiation dose at the same time. Analysis of myocardial strain provides incremental value in the context of complex cardiac structures including cardiac masses. 
CT can evaluate the extracellular volume to identify infiltration and fibrosis [43]. CT or coronary angiography can be performed to diagnose coronary aneurysms (Figure 10).
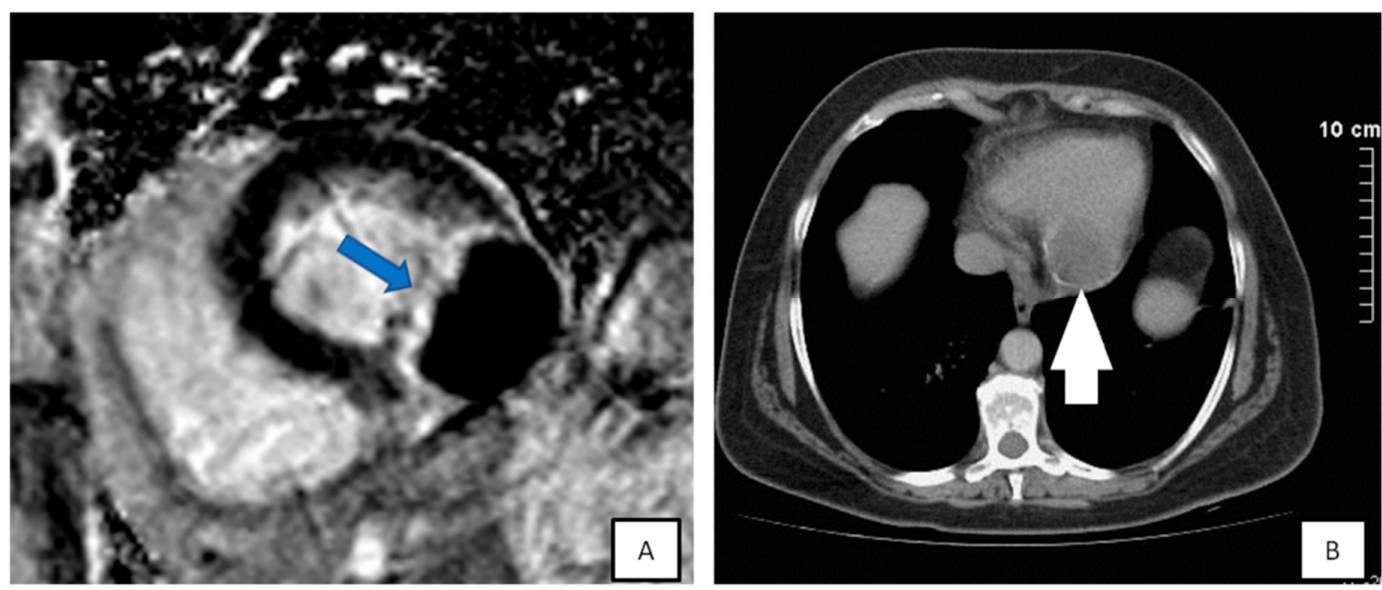

Figure 9. (A) Short-axis of late-gadolinium enhancement image demonstrating the echinococcus cyst attached to inferolateral wall, highly hypointense with hyperintense border (blue arrow). (B) CT demonstrated a calcified cyst (white arrow) proved to be a cardiac echinococcus cyst.
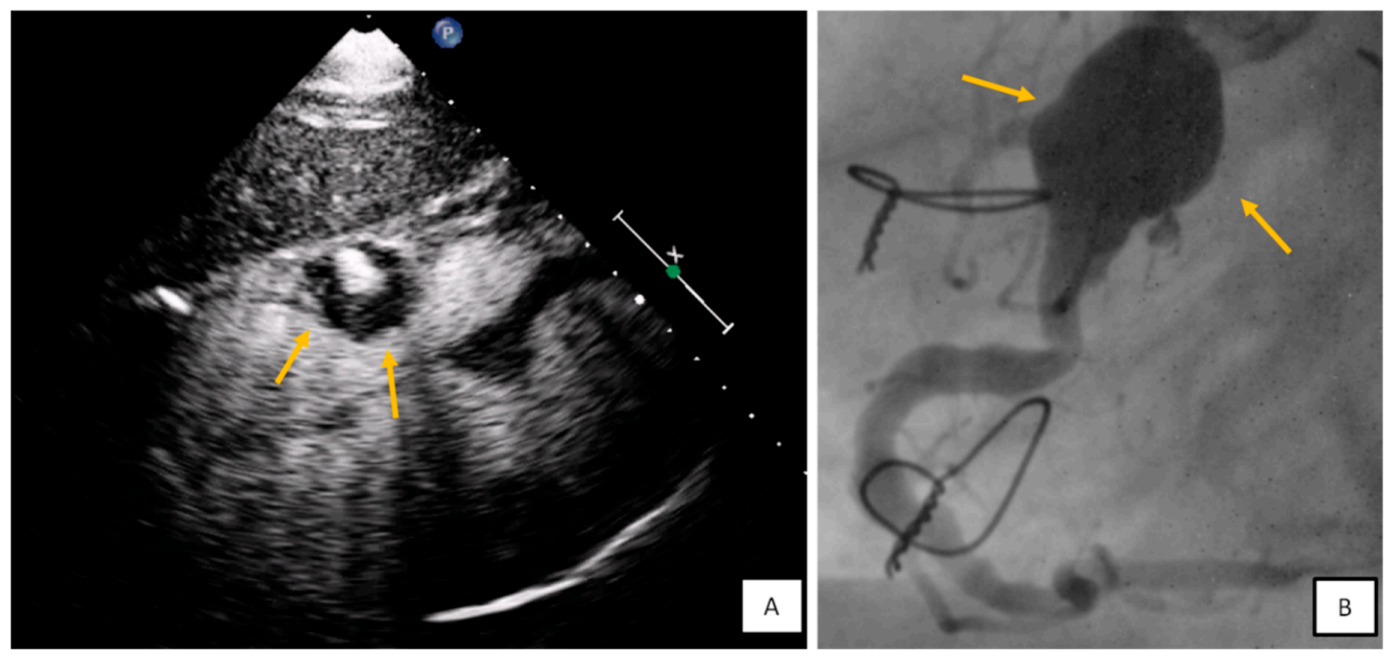

Figure 10. (A) Subxiphoid view with contrast agent. Round mass with mural thrombus and blood flow at the level of tricuspid annulus findings consistent with right coronary artery (RCA) aneurysm.

(B) Coronary angiography confirmed the diagnosis.

\subsection{Cardiac Magnetic Resonance}

CMR has adequate spatial and temporal resolution, and enables multi-planar reconstruction. It has tissue characterization capabilities due to inherent soft-tissue contrast, which can be brought out by using different tissue-weighted sequences and augmented by the administration of gadolinium-based contrast agents [44]. CMR differentiates benign from malignant cardiac masses, with tumor size, heterogeneity of signal intensity, local infiltration, and enhanced initial perfusion being the most reliable indicators of malignancy [38,45-47]. 3D-MRA is a new sequence that diagnoses cardiac tumors and can also disclose vascular involvement. Tumor vascularization can also be assessed by other perfusion techniques (contrast echo, angiography) [30,39,45]. Hence, concerning patients with malignant tumors, CMR offers complementary information and helps in diagnosis and patient's management.

On the other hand, it may not recognize effectively some small and highly mobile benign masses previously depicted with echocardiography [48]. CMR, when compared to CT, is superior for tissue characterization and reveals presence of fat tissue, degree of tissue edema and iron content of the 
cells $[36,39,49]$. CMR does not expose patients to ionizing radiation, but has lower spatial resolution and is inferior in detecting mass calcification. Performing a CMR study is more time consuming and need more coordinative patients. 3D reconstruction is available for both techniques and can be used for preoperative planning [42]. In infants and children, echocardiography is even more frequently used because of the limitations of CMR and cardiac CT [50]. However, when available, CMR can in most cases predict the tumor type in pediatric patients [51,52].

Specific considerations related to CMR imaging include:

1. Tissue characterization on T1-T2 weighted images:

- Imaging characteristic of hemorrhagic pericardial effusion and clots depends on the age of the effusion.

- Contrast enhancement during the first pass T1 weighted imaging is indicative of increased vasculature.

- T1 hypo/isointensity with high T2 weighted signal intensity characterizes the majority of benign or malignant cardiac tumors

- Apical and hypertrophic cardiomyopathy may mimic cardiac tumors such as fibromas. In such cases fibromas appear hypointense in T2 weighted images while hypertrophic cardiomyopathy hyperintense. Moreover, CMR tagging can highlight the contractile nature of hypertrophic cardiomyopathy $[53,54]$. High T1 and low T2 weighted signal intensity is indicative of metastatic malignant melanoma.

- High T1 signal intensity is also seen in lipomas. These masses and other lipomatoses can be recognized with fat suppression techniques (Figure 11).

2. Early gadolinium enhancement (EGE) which identifies thrombus from the adjacent hypokinetic cardiac wall.

3. Late gadolinium enhancement (LGE) that is ideal for fibrosis and necrosis identification.

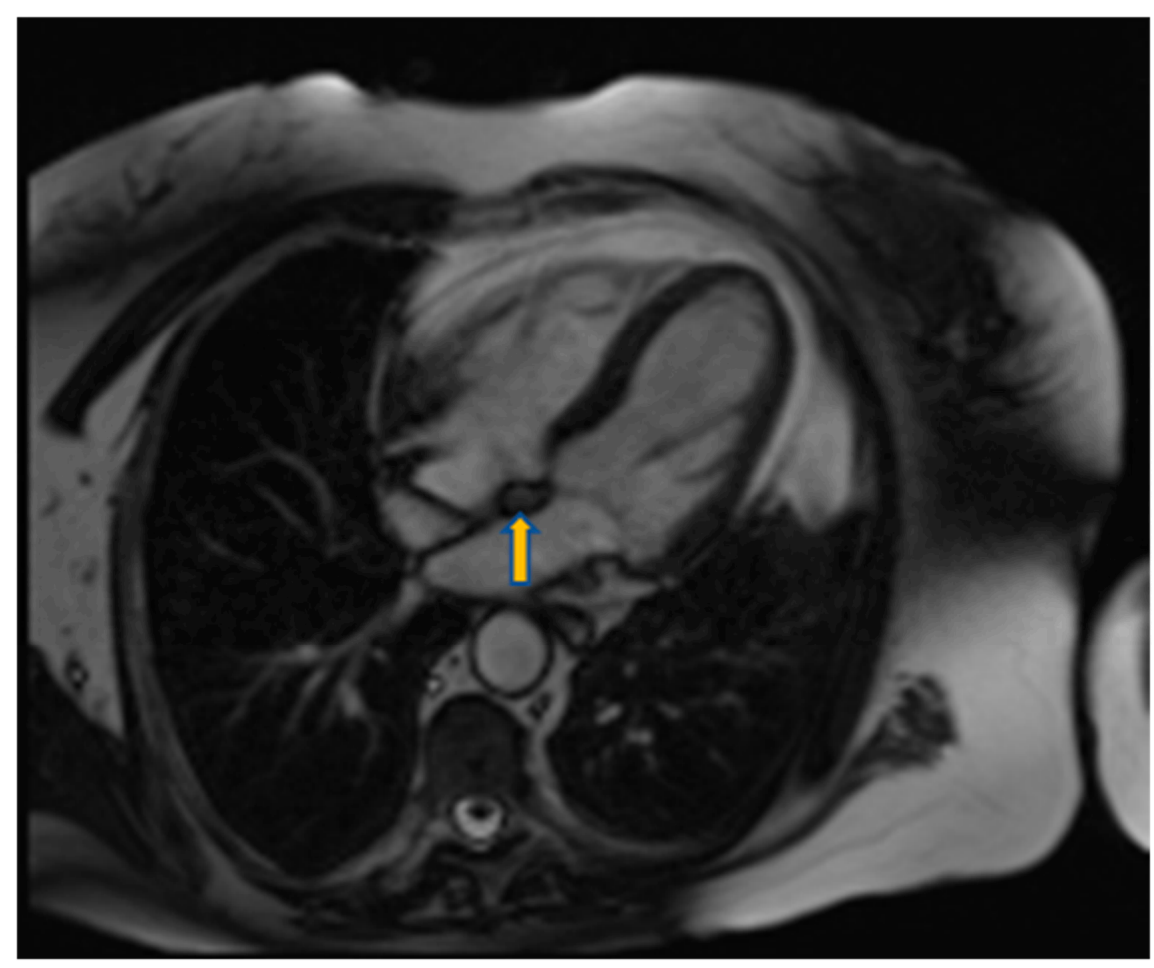

Figure 11. Four chamber view using SSFP sequence of a 70-year-old man showing lipomatous hypertrophy of the atrial septum (arrow). 


\subsection{Positron Emission Tomography}

Furthermore, ${ }^{18} \mathrm{~F}$ FDG-PET provides valuable information on the metabolic activity of cardiac tumors, differentiates benign from malignant cardiac tumors and predicts survival $[7,55,56]$. When there is no ${ }^{18} \mathrm{~F}$-FDG uptake in a lesion, malignancy can be excluded in most cases. False-positive ${ }^{18} \mathrm{~F}$-FDG uptake can be seen in inadequate patient preparation, inflammatory conditions (e.g., sarcoidosis), infections, abscesses, surgical changes, radiation changes, and brown fat. Other hybrid modalities (PET/MRI) have further incremental value $[56,57]$. Hence, in cases that the malignant nature of the cardiac mass is still under question, PET/CT or PET/MRI can be used to increase the diagnostic accuracy and/or to define the staging of the patient with malignancy, so that oncology team can propose and initiate further medical care.

\section{Conclusions}

The differential diagnosis of the cardiac masses is critical for the clinical management of the patient. Patient history and clinical examination are evaluated in combination with cardiovascular imaging data. Experience when performing TTE or TEE and application of newer echocardiographic techniques such as contrast echocardiography, usually set the initial diagnosis and guide further work-up with the use of CT, CMR, and ${ }^{18} \mathrm{~F}$ FDG PET-CT. The latter offer additional incremental information regarding diagnosis, therapeutic management and prognosis (Figure 12).

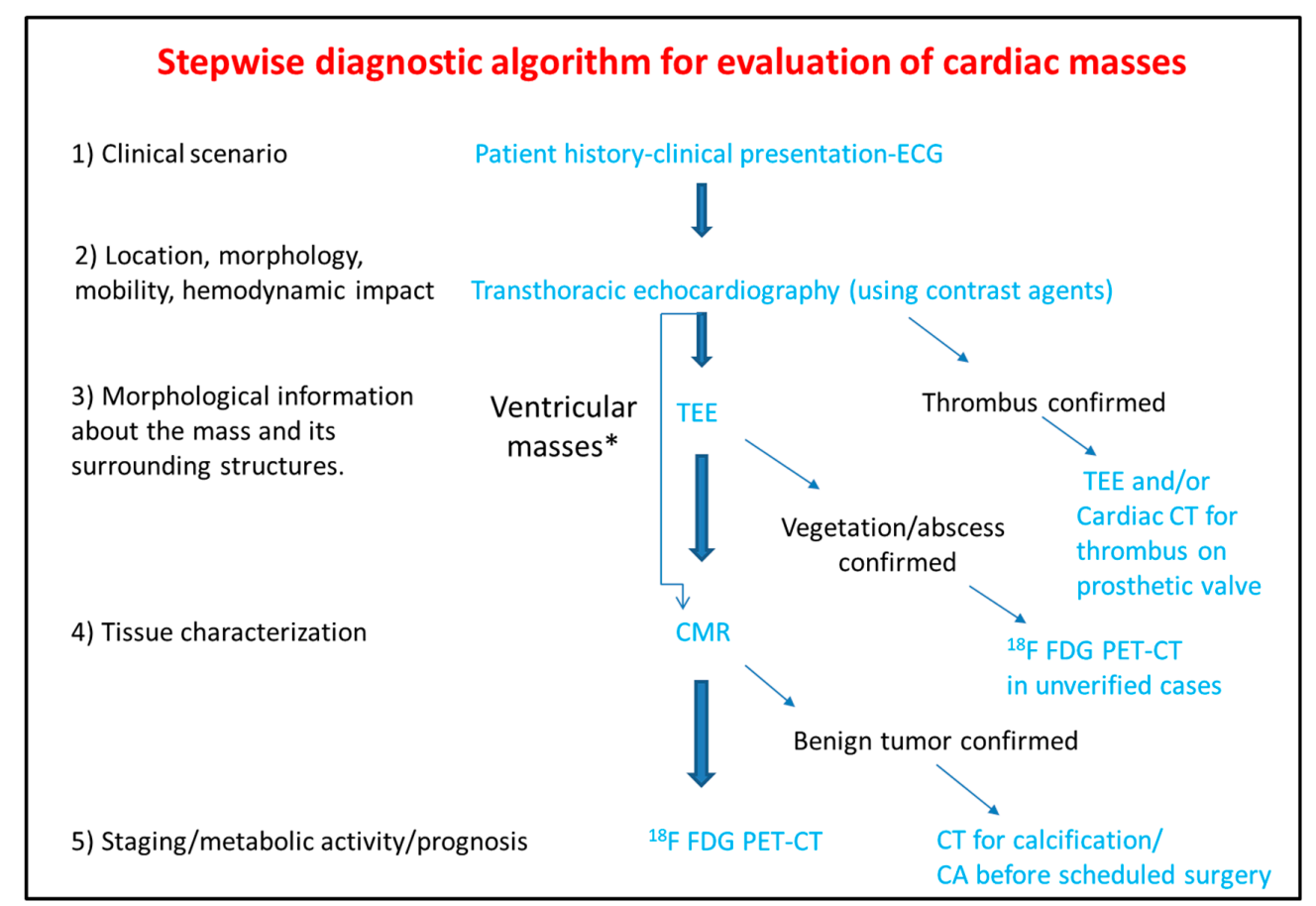

Figure 12. Step-by-step diagnostic algorithm for cardiac masses using cardiovascular imaging. Patient's history, clinical data and ECG should be acquired and evaluated before extensive imaging work-up. With data extracted by the clinical evaluation and the TTE, a physician may initiate differential diagnosis and plan further work-up approach. When the mass is proved to be a thrombus (consider using ultrasound enhancing agents) no further work-up is needed. When thrombus is found on a prosthetic valve, TEE and/or CT can also be used. The next step is TEE especially for atrial masses. When the mass is vegetation or abscess then usually no-further work up is needed (consider PET scan as next best step when diagnosis is still under question). For other masses CMR is the next best step and guides further work-up which could include CT, or ${ }^{18} \mathrm{~F} \mathrm{FDG} \mathrm{*} \mathrm{For} \mathrm{ventricular} \mathrm{masses} \mathrm{which} \mathrm{are}$ not adjacent to the cardiac valves and are not highly mobile, CMR can be alternatively used after the transthoracic echocardiogram without the need of TEE. 
PET-CT.ECG: Electrocardiogram; TEE: Transesophageal echocardiogram; CMR: Cardiac magnetic resonance; CT: Computed tomography; ${ }^{18} \mathrm{~F}$ FDG PET: Fluorodeoxyglycose positron emission tomography; CA: Coronary angiography.

Author Contributions: C.A., Y.D. and L.R. reviewed the literature and drafted the manuscript. G.S. and S.M. reviewed the literature and contributed to the manuscript drafting. J.W. and E.T. revised the manuscript and contributed to the manuscript drafting. C.T. had the general responsibility for revising the manuscript. All authors have read and agreed to the published version of the manuscript.

Funding: This research received no external funding.

Conflicts of Interest: The authors declare no conflict of interest.

Ethical Approval: The manuscript does not contain clinical studies or identifiable patient's data. The authors comply with international, national and institutional ethical standards.

\section{References}

1. Basso, C.; Rizzo, S.; Valente, M.; Thiene, G. Cardiac masses and tumours. Heart 2016, 102, 1230-1245. [CrossRef]

2. Butany, J.; Nair, V.; Naseemuddin, A.; Nair, G.M.; Catton, C.; Yau, T. Cardiac tumours: Diagnosis and management. Lancet Oncol. 2005, 6, 219-228. [CrossRef]

3. Capotosto, L.; Elena, G.; Massoni, F.; De Sio, S.; Carnevale, A.; Ricci, S.; Vitarelli, A. Cardiac tumors: Echocardiographic diagnosis and forensic correlations. Am. J. Forensic Med. Pathol. 2016, 37, 306-316. [CrossRef]

4. Rahouma, M.; Arisha, M.J.; Elmously, A.; El-Sayed Ahmed, M.M.; Spadaccio, C.; Mehta, K.; Baudo, M.; Kamel, M.; Mansor, E.; Ruan, Y.; et al. Cardiac tumors prevalence and mortality: A systematic review and meta-analysis. Int. J. Surg. 2020, 76, 178-189. [CrossRef]

5. Taguchi, S. Comprehensive review of the epidemiology and treatments for malignant adult cardiac tumors. Gen. Thorac. Cardiovasc. Surg. 2018, 66, 257-262. [CrossRef]

6. Butany, J.; Leong, S.W.; Carmichael, K.; Komeda, M. A 30-year analysis of cardiac neoplasms at autopsy. Can. J. Cardiol. 2005, 21, 675-680.

7. Lemasle, M.; Lavie Badie, Y.; Cariou, E.; Fournier, P.; Porterie, J.; Rousseau, H.; Petermann, A.; Hitzel, A.; Carrié, D.; Galinier, M.; et al. Contribution and performance of multimodal imaging in the diagnosis and management of cardiac masses. Int. J. Cardiovasc. Imaging 2020, 36, 971-981. [CrossRef]

8. Anvari, M.S.; Naderan, M.; Babaki, A.E.S.; Shoar, S.; Boroumand, M.A.; Abbasi, K. Clinicopathologic review of non-myxoma cardiac tumors: A 10-year single-center experience. Cardiology 2014, 129, 199-202. [CrossRef]

9. Wang, J.G.; Wang, B.; Hu, Y.; Liu, J.H.; Liu, B.; Liu, H.; Zhao, P.; Zhang, L.; Li, Y.J. Clinicopathologic features and outcomes of primary cardiac tumors: A 16-year-experience with 212 patients at a Chinese medical center. Cardiovasc. Pathol. 2018, 33, 45-54. [CrossRef]

10. Basso, C.; Valente, M.; Poletti, A.; Casarotto, D.; Thiene, G. Surgical pathology of primary cardiac and pericardial tumors. Eur. J. Cardio-Thorac. Surg. 1997, 12, 730-738. [CrossRef]

11. Grebenc, M.L.; Rosado De Christenson, M.L.; Burke, A.P.; Green, C.E.; Galvin, J.R. Primary cardiac and pericardial neoplasms: Radiologic-pathologic correlation. Radiographics 2000, 20, 1073-1103. [CrossRef] [PubMed]

12. Abraham, K.P.; Reddy, V.; Gattuso, P. Neoplasms metastatic to the heart: Review of 3314 consecutive autopsies. Am. J. Cardiovasc. Pathol. 1990, 3, 195-198. [PubMed]

13. Burazor, I.; Aviel-Ronen, S.; Imazio, M.; Goitein, O.; Perelman, M.; Shelestovich, N.; Radovanovic, N.; Kanjuh, V.; Barshack, I.; Adler, Y. Metastatic cardiac tumors: From clinical presentation through diagnosis to treatment. BMC Cancer 2018, 18, 1-9. [CrossRef] [PubMed]

14. Bussani, R.; De-Giorgio, F.; Abbate, A.; Silvestri, F. Cardiac metastases. J. Clin. Pathol. 2007, 60, $27-34$. [CrossRef]

15. Lee, E.; Mahani, M.G.; Lu, J.C.; Dorfman, A.L.; Srinivasan, A.; Agarwal, P.P. Primary cardiac tumors associated with genetic syndromes: A comprehensive review. Pediatr. Radiol. 2018, 48, 156-164. [CrossRef]

16. Beghetti, M.; Gow, R.M.; Haney, I.; Mawson, J.; Williams, W.G.; Freedom, R.M. Pediatric primary benign cardiac tumors: A 15-year review. Am. Heart J. 1997, 134, 1107-1114. 
17. Shi, L.; Wu, L.; Fang, H.; Han, B.; Yang, J.; Ma, X.; Liu, F.; Zhang, Y.; Xiao, T.; Huang, M.; et al. Identification and clinical course of 166 pediatric cardiac tumors. Eur. J. Pediatr. 2017, 176, 253-260. [CrossRef]

18. Paraskevaidis, I.A.; Michalakeas, C.A.; Papadopoulos, C.H.; Anastasiou-Nana, M. Cardiac Tumors. ISRN Oncol. 2011, 2011, 208929. [CrossRef]

19. Burazor, I.; Aviel-Ronen, S.; Imazio, M.; Markel, G.; Grossman, Y.; Yosepovich, A.; Adler, Y. Primary malignancies of the heart and pericardium. Clin. Cardiol. 2014, 37, 582-588. [CrossRef]

20. Yanagawa, B.; Chan, E.Y.; Cusimano, R.J.; Reardon, M.J. Approach to Surgery for Cardiac Tumors: Primary Simple, Primary Complex, and Secondary. Cardiol. Clin. 2019, 37, 525-531. [CrossRef]

21. Yusuf, S.W.; Reardon, M.J.; Banchs, J. Cardiac tumors. Cardiology 2014, 129, 197-198. [CrossRef] [PubMed]

22. Burke, A.; Tavora, F. The 2015 WHO Classification of tumors of the heart and pericardium. J. Thorac. Oncol. 2016, 11, 441-452. [CrossRef] [PubMed]

23. Colin, G.C.; Gerber, B.L.; Amzulescu, M.; Bogaert, J. Cardiac myxoma: A contemporary multimodality imaging review. Int. J. Cardiovasc. Imaging 2018, 34, 1789-1808. [CrossRef] [PubMed]

24. Neuville, A.; Collin, F.; Bruneval, P.; Parrens, M.; Thivolet, F.; Gomez-Brouchet, A.; Terrier, P.; De Montpreville, V.T.; Le Gall, F.; Hostein, I.; et al. Intimal sarcoma is the most frequent primary cardiac sarcoma: Clinicopathologic and molecular retrospective analysis of 100 primary cardiac sarcomas. Am. J. Surg. Pathol. 2014, 38, 461-469. [CrossRef]

25. Tsugu, T.; Nagatomo, Y.; Endo, J.; Kawakami, T.; Murata, M.; Yamazaki, M.; Shimizu, H.; Fukuda, K.; Mitamura, H.; Lancellotti, P. Multiple papillary fibroelastomas attached to left ventricular side and aortic side of the aortic valve: A report of new case and literature review. Echocardiography 2019, 36, 1194-1199. [CrossRef]

26. Yanagawa, B.; Mazine, A.; Chan, E.Y.; Barker, C.M.; Gritti, M.; Reul, R.M.; Ravi, V.; Ibarra, S.; Shapira, O.M.; Cusimano, R.J.; et al. Surgery for Tumors of the Heart. Semin. Thorac. Cardiovasc. Surg. 2018, 30, 385-397. [CrossRef]

27. Castillo, J.G.; Silvay, G. Characterization and management of cardiac tumors. Semin. Cardiothorac. Vasc. Anesth. 2010, 14, 6-20. [CrossRef]

28. Altbach, M.I.; Squire, S.W.; Kudithipudi, V.; Castellano, L.; Sorrell, V.L. Cardiac MRI is complementary to echocardiography in the assessment of cardiac masses. Echocardiography 2007, 24, 286-300. [CrossRef]

29. Ragland, M.M.; Tak, T. The role of echocardiography in diagnosing space-occupying lesions of the heart. Clin. Med. Res. 2006, 4, 22-32. [CrossRef]

30. Wang, X.; Li, Y.; Ren, W.; Yu, X.; Tan, X. Clinical diagnostic value of contrast-enhanced ultrasonography in the diagnosis of cardiac masses: A pilot study. Echocardiography 2020, 37, 231-238. [CrossRef]

31. Palaskas, N.; Thompson, K.; Gladish, G.; Agha, A.M.; Hassan, S.; Iliescu, C.; Kim, P.; Durand, J.B.; Lopez-Mattei, J.C. Evaluation and Management of Cardiac Tumors. Curr. Treat. Options Cardiovasc. Med. 2018, 20, 29. [CrossRef] [PubMed]

32. Strachinaru, M.; Damry, N.; Duttmann, R.; Wauthy, P.; Catez, E.; Lutea, M.; Costescu, I.; Morissens, M. Ultrasound Contrast Quantification for the Diagnosis of Intracardiac Masses. JACC Cardiovasc. Imaging 2016, 9, 747-750. [CrossRef] [PubMed]

33. Wu, C.M.; Bergquist, P.J.; Srichai, M.B. Multimodality Imaging in the Evaluation of Intracardiac Masses. Curr. Treat. Options Cardiovasc. Med. 2019, 21, 55. [CrossRef] [PubMed]

34. Zaragosa-Macias, E.; Chen, M.A.; Gill, E.A. Real time three-dimensional echocardiography evaluation of intracardiac masses. Echocardiography 2012, 29, 207-219. [CrossRef] [PubMed]

35. Aggeli, C.; Poulidakis, E.; Felekos, I.; Aggeli, A.; Stefanadis, C. An octopus-like myxoma depicted by real-time 3D transesophageal echocardiography. Hell. J. Cardiol. 2012, 53, 470-471.

36. Li, X.; Chen, Y.; Liu, J.; Xu, L.; Li, Y.; Liu, D.; Sun, Z.; Wen, Z. Cardiac magnetic resonance imaging of primary cardiac tumors. Quant. Imaging Med. Surg. 2020, 10, 294-313. [CrossRef]

37. Araoz, P.A.; Mulvagh, S.L.; Tazelaar, H.D.; Julsrud, P.R.; Breen, J.F. CT and MR imaging of benign primary cardiac neoplasms with echocardiographic correlation. Radiographics 2000, 20, 1303-1319. [CrossRef]

38. Hoffmann, U.; Globits, S.; Schima, W.; Loewe, C.; Puig, S.; Oberhuber, G.; Frank, H. Usefulness of magnetic resonance imaging of cardiac and paracardiac masses. Am. J. Cardiol. 2003, 92, 890-895. [CrossRef] 
39. Auger, D.; Pressacco, J.; Marcotte, F.; Tremblay, A.; Dore, A.; Ducharme, A. Cardiac masses: An integrative approach using echocardiography and other imaging modalities. Heart 2011, 97, 1101-1109. [CrossRef]

40. Kassop, D.; Donovan, M.S.; Cheezum, M.K.; Nguyen, B.T.; Gambill, N.B.; Blankstein, R.; Villines, T.C. Cardiac Masses on Cardiac CT: A Review. Curr. Cardiovasc. Imaging Rep. 2014, 7, 1-13. [CrossRef]

41. Hong, Y.J.; Hur, J.; Kim, Y.J.; Lee, H.J.; Hong, S.R.; Suh, Y.J.; Kim, H.Y.; Lee, J.W.; Choi, B.W. Dual-energy cardiac computed tomography for differentiating cardiac myxoma from thrombus. Int. J. Cardiovasc. Imaging 2014, 30, 121-128. [CrossRef] [PubMed]

42. Liddy, S.; McQuade, C.; Walsh, K.P.; Loo, B.; Buckley, O. The Assessment of Cardiac Masses by Cardiac CT and CMR Including Pre-op 3D Reconstruction and Planning. Curr. Cardiol. Rep. 2019, 21, 103. [CrossRef] [PubMed]

43. Nicol, E.D.; Norgaard, B.L.; Blanke, P.; Ahmadi, A.; Weir-McCall, J.; Horvat, P.M.; Han, K.; Bax, J.J.; Leipsic, J. The Future of Cardiovascular Computed Tomography: Advanced Analytics and Clinical Insights. JACC Cardiovasc. Imaging 2019, 12, 1058-1072. [CrossRef] [PubMed]

44. Pazos-López, P.; Pozo, E.; Siqueira, M.E.; García-Lunar, I.; Cham, M.; Jacobi, A.; Macaluso, F.; Fuster, V.; Narula, J.; Sanz, J. Value of CMR for the differential diagnosis of cardiac masses. JACC Cardiovasc. Imaging 2014, 7, 896-905. [CrossRef]

45. Luna, A.; Ribes, R.; Caro, P.; Vida, J.; Erasmus, J.J. Evaluation of cardiac tumors with magnetic resonance imaging. Eur. Radiol. 2005, 15, 1446-1455. [CrossRef]

46. Giusca, S.; Mereles, D.; Ochs, A.; Buss, S.; André, F.; Seitz, S.; Riffel, J.; Fortner, P.; Andrulis, M.; Schönland, S.; et al. Incremental value of cardiac magnetic resonance for the evaluation of cardiac tumors in adults: Experience of a high volume tertiary cardiology centre. Int. J. Cardiovasc. Imaging 2017, 33, 879-888. [CrossRef]

47. Mousavi, N.; Cheezum, M.K.; Aghayev, A.; Padera, R.; Vita, T.; Steigner, M.; Hulten, E.; Bittencourt, M.S.; Dorbala, S.; Di Carli, M.F.; et al. Assessment of Cardiac Masses by Cardiac Magnetic Resonance Imaging: Histological Correlation and Clinical Outcomes. J. Am. Heart Assoc. 2019, 8, e007829. [CrossRef]

48. Tumma, R.; Dong, W.; Wang, J.; Litt, H.; Han, Y. Evaluation of cardiac masses by CMR—Strengths and pitfalls: A tertiary center experience. Int. J. Cardiovasc. Imaging 2016, 32, 913-920. [CrossRef]

49. O'Donnell, D.H.; Abbara, S.; Chaithiraphan, V.; Yared, K.; Killeen, R.P.; Cury, R.C.; Dodd, J.D. Cardiac tumors: Optimal cardiac MR sequences and spectrum of imaging appearances. Am. J. Roentgenol. 2009, 193, 377-387. [CrossRef]

50. Tzani, A.; Doulamis, I.P.; Mylonas, K.S.; Avgerinos, D.V.; Nasioudis, D. Cardiac Tumors in Pediatric Patients: A Systematic Review. World J. Pediatr. Congenit. Heart Surg. 2017, 8, 624-632. [CrossRef]

51. Beroukhim, R.S.; Prakash, A.; Valsangiacomo Buechel, E.R.; Cava, J.R.; Dorfman, A.L.; Festa, P.; Hlavacek, A.M.; Johnson, T.R.; Keller, M.S.; Krishnamurthy, R.; et al. Characterization of cardiac tumors in children by cardiovascular magnetic resonance imaging: A multicenter experience. J. Am. Coll. Cardiol. 2011, 58, 1044-1054. [CrossRef] [PubMed]

52. Fournier, E.; Séguéla, P.-E.; Sauvestre, F.; Jalal, Z.; Thomas, J.; Iriart, X.; Bonello, B.; Thambo, J.-B. Imaging Aspects of Pediatric Cardiac Tumors. J. Am. Coll. Cardiol. Cardiovasc. Imaging 2020, 13, 2245-2253. [CrossRef] [PubMed]

53. Nucifora, G.; Pasotti, E.; Pedrazzini, G.; Moccetti, T.; Faletra, F.F.; Gallino, A. Cardiac fibroma mimicking hypertrophic cardiomyopathy: Role of magnetic resonance imaging in the differential diagnosis. Int. J. Cardiol. 2012, 154, e11-e13. [CrossRef] [PubMed]

54. Noureldin, R.A.; Liu, S.; Nacif, M.S.; Judge, D.P.; Halushka, M.K.; Abraham, T.P.; Ho, C.; Bluemke, D.A. The diagnosis of hypertrophic cardiomyopathy by cardiovascular magnetic resonance. J. Cardiovasc. Magn. Reson. 2012, 14, 17. [CrossRef]

55. Meng, J.; Zhao, H.; Liu, Y.; Chen, D.; Hacker, M.; Wei, Y.; Li, X.; Zhang, X.; Kreissl, M.C. Assessment of cardiac tumors by ${ }^{18}$ F-FDG PET/CT imaging: Histological correlation and clinical outcomes. J. Nucl. Cardiol. 2020. [CrossRef]

56. Chalian, H.; O'Donnell, J.K.; Bolen, M.; Rajiah, P. Incremental value of PET and MRI in the evaluation of cardiovascular abnormalities. Insights Imaging 2016, 7, 485-503. [CrossRef] 
57. Fathala, A.; Abouzied, M.; AlSugair, A.-A. Cardiac and pericardial tumors: A potential application of positron emission tomography-magnetic resonance imaging. World J. Cardiol. 2017, 9, 600. [CrossRef]

Publisher's Note: MDPI stays neutral with regard to jurisdictional claims in published maps and institutional affiliations.

(C) 2020 by the authors. Licensee MDPI, Basel, Switzerland. This article is an open access article distributed under the terms and conditions of the Creative Commons Attribution (CC BY) license (http://creativecommons.org/licenses/by/4.0/). 